\title{
Effect of prepartum energy intake and supplementation with ruminally protected choline on innate and adaptive immunity of multiparous Holstein cows
}

\author{
M. G. Zenobi, ${ }^{1}$ R. Gardinal, ${ }^{1 \star}$ J. E. Zuniga, ${ }^{1} \dagger$ L. K. Mamedova, ${ }^{2}$ J. P. Driver, ${ }^{1}$ B. A. Barton, ${ }^{3} \ddagger$ J. E. P. Santos, ${ }^{1}$ \\ C. R. Staples, ${ }^{1}$ and C. D. Nelson ${ }^{1} \S$ \\ ${ }^{1}$ Department of Animal Sciences, University of Florida, Gainesville 32611 \\ ${ }^{2}$ Department of Animal Sciences and Industry, Kansas State University, Manhattan 66506 \\ ${ }^{3}$ Balchem Corp., New Hampton, NY 10958
}

\begin{abstract}
Objectives were to evaluate the effect of prepartum energy intake and peripartal supplementation of ruminally protected choline (RPC) on select indicators of immune status in blood plasma and on lipopolysaccharide-stimulated blood cells ex vivo. At $47 \pm 6$ d before the expected calving date, 93 multiparous Holstein cows were assigned randomly to 1 of 4 dietary treatments in a $2 \times 2$ factorial arrangement. Cows were fed energy to excess [EXE; 1.63 Mcal of net energy for lactation $\left(\mathrm{NE}_{\mathrm{L}}\right) / \mathrm{kg}$ of dietary dry matter $(\mathrm{DM})$ ] or to maintenance (MNE; 1.40 Mcal of $\mathrm{NE}_{\mathrm{L}} / \mathrm{kg}$ of dietary DM) ad libitum throughout the nonlactating period. The RPC was fed at 0 or $60 \mathrm{~g} / \mathrm{d}$ to supply 0 or $12.9 \mathrm{~g} / \mathrm{d}$ of choline ions top-dressed for $17 \pm 4.6 \mathrm{~d}$ prepartum through $21 \mathrm{~d}$ postpartum. After calving, cows were fed the same methionine-supplemented diet, apart from RPC supplementation. During the last 2 wk before calving and during the first 5 wk postpartum, blood was sampled repeatedly and analyzed for cell types, acute-phase proteins, tumor necrosis factor- $\alpha$ (TNF $\alpha$ ), and neutrophil function. Samples of whole blood were collected at 3 and 14 DIM and stimulated with $1 \mu \mathrm{g} /$ $\mathrm{mL}$ lipopolysaccharide (LPS) in vitro for 6 and $24 \mathrm{~h}$. After $6 \mathrm{~h}$ of LPS exposure, peripheral blood leucocytes (PBL) were harvested, and relative transcript abundance for select cytokines were measured. Supernatant was analyzed for TNF $\alpha$ after $24 \mathrm{~h}$ of LPS exposure. The PBL from cows fed EXE diets during the whole dry
\end{abstract}

Received August 1, 2019.

Accepted November 19, 2019.

*Current address: Department of Animal Nutrition and Production, University of São Paulo, 13635-900, Pirassununga, Brazil.

Rica.

†Current address: San Isidro, Perez Zeledon, San José 30701, Costa

$\ddagger$ Current address: 52 Sunrise Park Rd, Balchem Corp., New Hampton, NY 10958.

§Corresponding author: cdnelson@ufl.edu period had increased transcripts for the proinflammatory cytokines $C X C L 8$ and $T N F$, although the plasma concentrations of the acute-phase proteins haptoglobin and fibrinogen, and the killing activity of the blood neutrophils in the postpartum period, were not affected by feeding different energy levels prepartum. Feeding RPC to cows overfed energy prepartum modulated their inflammatory state, as evidenced by decreased IL 6 in PBL and reduced mean fluorescence intensity of CD14 during the postpartum period, compared with cows not fed RPC. Feeding RPC also decreased TNFo protein production, abundances of IL1B, CXCL8, and TNF transcripts, and mean fluorescence intensity of CD80 of PBL stimulated by LPS, regardless of prepartum energy intake. In contrast, proportions of blood neutrophils undergoing phagocytosis and oxidative burst were increased at $17 \mathrm{~d}$ postpartum in cows supplemented with RPC. Collectively, these data indicate that transition cows supplemented with RPC experienced less inflammation, which may partially explain increased milk production in cows supplemented with RPC.

Key words: choline, inflammation, lipopolysaccharide, neutrophils, transition cow

\section{INTRODUCTION}

The majority of production-related diseases in highyielding dairy cows occur during early lactation, and some have been associated with insufficient intake of energy and metabolic imbalance (Ingvartsen et al., 2003). The production-related diseases are arguably attributable to management of the prepartum diet. Scientific efforts in this area, however, have provided inconsistent results, particularly related to prevention of diseases associated with metabolic imbalances. Therefore, the appropriate type of diet to feed during the prepartum period remains to a large extent unclear. For instance, overconsumption of energy during the entire dry period resulted in greater milk yield in the first weeks 
postpartum without a corresponding increase in feed intake postpartum; rather, a greater loss of BW and a more negative energy state was reported (Janovick and Drackley, 2010). A recent experiment reported less DM intake, no change in milk yield, a more negative energy balance, and increased hepatic triacylglycerol content in multiparous cows overfed energy compared with cows fed to maintenance for the entire dry period (Zenobi et al., 2018a).

Sufficient data support a strong relationship between excessive mobilization of body fat in early lactation and incidence of metabolic diseases such as fatty liver and ketosis (Grummer, 1993). Excessive mobilization of body fat, in turn, can hamper metabolism and compromise neutrophil function (Zerbe et al., 2000; Graugnard et al., 2013). For example, phagocytosis by blood neutrophils at 14 DIM decreased $7 \mathrm{~d}$ after an intramammary LPS challenge if the cows had been overfed during the prepartum period (Moyes et al., 2014). Hence, overconsumption of calories prepartum may compromise the immune status of postpartum cows.

Choline is an important lipotropic compound in mammals and promotes the export of lipids from the liver as a component of very low density lipoproteins (Chandler and White, 2017). Feeding ruminally protected choline (RPC) during the periparturient period has led to decreased hepatic triacylglycerol concentration and increased milk yield (Elek et al., 2013; Zenobi et al., 2018a). This lipotropic effect of choline has been suggested as the main mechanism by which RPC supplementation around parturition increases milk yield (Pinotti, 2012). Conversely, the consistent increase in milk yield obtained by supplementing RPC is not always accompanied by an increase in feed intake or by increased mobilization of body reserves or by decreased concentration of hepatic triacylglycerol (Shahsavari et al., 2016). Thus, additional mechanisms may contribute toward the consistent improvement in milk production reported for transition dairy cows supplemented with RPC. In a recent study we hypothesized that greater milk yield by dairy cows fed RPC may be due partially to improved utilization of feed nutrients by enhancing the integrity of enterocyte membranes (Zenobi et al., 2018a). In addition, the role of RPC may help decrease inflammation (Sun et al., 2016; Vailati-Riboni et al., 2017), which, in turn, may improve cow performance (Sun et al., 2016) by modulating the costs of energy to support the immune system.

Certain phospholipids located at the mammalian cell membrane play important roles in immune responses to bacterial infections via modulating membrane fluidity and intracellular signaling pathways. The lipid bilayer of cell membranes is composed mainly of phosphatidylcholine and phosphatidylinositol. Feeding of cho- line may increase the ratio of phosphatidylcholine to polyphosphoinositides in the cell membrane, as RPC supplementation of cows increased plasma concentrations of the lipid-soluble choline biomolecules (e.g., phosphatidylcholine, lysophosphatidylcholine, and sphingomyelin; Zenobi et al., 2018b). Increased content of phosphatidylcholine in the cell membrane were reported to decrease macrophage $\mathrm{TNF} \alpha$ production (Grove et al., 1990), supposedly by limiting the polyphosphoinositide induction intracellular $\mathrm{Ca}^{2+}$ release in response to LPS (Rivera et al., 1998). Accordingly, choline supplementation dramatically decreased the respiratory failure rate of rats injected with LPS (Rivera et al., 1998). Pro-inflammatory cytokines such as $\mathrm{TNF} \alpha$ induce a systemic acute-phase response characterized by fever, release of liver-derived acute-phase proteins, a drop in circulating concentrations of $\mathrm{Ca}^{2+}$, and fatty liver in dairy cows (Waldron et al., 2003; Bradford et al., 2009). In addition, lipoproteins, which are rich in phosphatidylcholine, can bind to the LPS of bacteria and prevent them from stimulating cells of the immune system, such as monocytes and macrophages, partially protecting the host from the toxic effects caused by these pathogens (Harris et al., 1993; Read et al., 1995).

The reported influence of choline on the pro-inflammatory responses of immune cells has relevance for postpartum diseases of dairy cows. Dairy cows have a decreased plasma concentration of phosphatidylcholine in the early postpartum period (Imhasly et al., 2015). The decrease in circulating phosphatidylcholine is quite possibly associated with a decrease in the ratio of phosphatidylcholine to phosphatidylinositol in cell membranes and, consequently, augmentation of intracellular signaling in response to activators of inflammatory responses, such as LPS, as others have shown in rodents (Grove et al., 1990; Rivera et al., 1998). Hence, we hypothesize that supplementation with RPC will modulate measures of inflammation and immune status of transition dairy cows, especially in those cows overfed calories during the prepartum period. The objectives of the present investigation were to study the effects of perinatal RPC supplementation and of prepartum caloric intake on (1) regulation of innate and adaptive immunity in vivo and on (2) gene expression by select interleukins of peripheral blood leukocytes (PBL) stimulated with LPS in vitro.

\section{MATERIALS AND METHODS}

\section{Cows, Dietary Treatments, and Management}

The experiment was conducted at the University of Florida dairy unit from November 2014 to September 2015. All procedures involving cows in the experiment 
were carried out according to the University of Florida's Institutional Animal Care and Use Committee.

A detailed description of the experiment's design and results was published previously (Zenobi et al., 2018a). In brief, at $47 \pm 6 \mathrm{~d}$ before the expected calving date, 93 pregnant, dry Holstein cows with at least 1 previous lactation (mean $\pm \mathrm{SD}=1.9 \pm 0.3$ ) were enrolled in the experiment. Selection criteria included apparently healthy cows with no history of chronic disease before enrollment and a 305-d mature equivalent milk yield greater than $6,800 \mathrm{~kg}$. Cows were assigned randomly to 1 of 4 treatments in a $2 \times 2$ factorial arrangement. One factor was RPC top-dressed at $0(-\mathbf{R P C})$ or $12.9 \mathrm{~g} / \mathrm{d}$ of choline ion (+RPC) from $21 \mathrm{~d}$ before expected calving date through $21 \mathrm{~d}$ postpartum. The RPC product was fed at $60 \mathrm{~g} / \mathrm{d}$ to supply the $12.9 \mathrm{~g} / \mathrm{d}$ of choline ion (ReaShure; Balchem Corp., New Hampton, NY). The second treatment factor was prepartum diets formulated to 1.63 (excess energy, EXE) or 1.40 (maintenance energy, MNE) Mcal of $\mathrm{NE}_{\mathrm{L}} / \mathrm{kg}$ of dietary DM fed ad libitum for the whole dry period. Therefore, the 4 treatments were EXE intake with $(\mathrm{n}=25)$ and without $(\mathrm{n}=22) \mathrm{RPC}$, and MNE intake with $(\mathrm{n}=21)$ and without $(\mathrm{n}=25)$ RPC.

\section{Measurements, Sample Collection, and Laboratory Analyses}

Plasma Collection and Measurements. Blood samples were collected at 12 and $7 \mathrm{~d}$ before the expected calving day and at $0,1,7,14,21$, and $35 \mathrm{~d}$ postpartum by puncture of the coccygeal vessels into evacuated tubes (Vacutainer, Becton Dickinson, Franklin Lakes, NJ) containing lithium heparin, and placed on ice. Within 30 min of collection, samples were centrifuged at 1,125 $\times \mathrm{g}$ for $20 \mathrm{~min}$, plasma was harvested, and multiple aliquots of $1.5 \mathrm{~mL}$ were frozen at $-20^{\circ} \mathrm{C}$ until further analyses.

Plasma concentrations of haptoglobin were measured $(-12,-7,0,7,14,21$, and $35 \mathrm{~d}$ relative to parturition) using a colorimetric procedure that measured haptoglobin-hemoglobin complexing by estimating differences in peroxidase activity (Makimura and Suzuki, 1982). Results were expressed as absolute absorbance values at $450 \mathrm{~nm}$ times 100. Samples were analyzed in duplicate, and the inter- and intra-assay coefficients of variation $(\mathrm{CV})$ were 5.2 and $6.4 \%$, respectively. Plasma concentrations of fibrinogen were measured $(-12,-7$, $0,7,14,21$, and $35 \mathrm{~d}$ relative to parturition) using a fibrinogen determination kit (TriniCLOT Fibrinogen kit No. T1301; Tcoag Ireland Ltd., Bray, Ireland) by estimating clotting time using a BBL Fibrometer coagulation analyzer (Rankin Biomedical Corp., Holly, MI).
The inter- and intra-assay CV of the duplicate samples were 9.2 and $13.0 \%$, respectively. Plasma concentrations of $\mathrm{TNF} \alpha$ were determined with an ELISA, as described by Farney et al. (2011), using bovine-specific antibodies (\#ENPBOTNFABI; ENPBOTNFAI) and bovine-specific recombinant protein (\#ENRBOTNFAI; Thermo Fisher Scientific, Waltham, MA) at 1, 7, 14, and 21 DIM. The inter- and intra-assay CV were 4.0 and $9.2 \%$, respectively.

Rectal Temperature. A complete physical examination that included rectal temperature (electronic thermometer; GLA Agricultural Products, San Luis Obispo, CA) was performed immediately after the morning milking at 4, 7, and 12 DIM. Fever was considered when rectal temperature was $\geq 39.5^{\circ} \mathrm{C}$.

Ex Vivo Immunological Analyses. Production of TNF $\alpha$ by PBL was measured ex vivo by stimulating whole blood with LPS at 3 and $14 \mathrm{~d}$ postpartum. Briefly, in a laminar airflow bench, $400 \mu \mathrm{L}$ of heparinized whole blood was diluted with $1,600 \mu \mathrm{L}$ of RPMI 1640 without HEPES medium (Cat No. 11875-085; Invitrogen Life Technologies Corp., Grand Island, $\mathrm{NY}$ ), containing a final concentration of $1 \%$ ( $\mathrm{vol} / \mathrm{vol})$ antibiotic-antimycotic (Cat No. 15240-062; Invitrogen), and pipetted into sterile 24-well cell culture plates (Sigma-Aldrich Co., St. Louis, MO). The culture was stimulated with commercially available LPS derived from Serratia marcescens (L6136; Sigma-Aldrich) at a final concentration of $0 \mu \mathrm{g} / \mathrm{mL}$ (-LPS) or $1 \mu \mathrm{g} / \mathrm{mL}$ of LPS (+LPS). Cell suspensions were incubated for 6 and $24 \mathrm{~h}$ at $37^{\circ} \mathrm{C}$ in a humidified atmosphere with $5 \% \mathrm{CO}_{2}$. The 6- and 24-h incubation times were selected on the basis of preliminary experiments and previous reports (Ballou et al., 2015; Merriman et al., 2019) showing that these times resulted in changes to gene expression and TNFa abundance in response to LPS stimulation. The culture media used in this experiment contained methionine $(15 \mathrm{mg} / \mathrm{L})$, serine $(30 \mathrm{mg} / \mathrm{L})$, folic acid (1 $\mathrm{mg} / \mathrm{L})$, and choline chloride $(3.0 \mathrm{mg} / \mathrm{L})$.

After $6 \mathrm{~h}$ of incubation, cell suspensions were centrifuged for $15 \mathrm{~min}$ at $1,200 \times g$ (Allegra X-15R centrifuge, Beckman Coulter Inc., Brea, CA) and supernatants were discarded. The remaining blood cells were suspended using $1.5 \mathrm{~mL}$ of cold hypotonic buffer (10.6 $\mathrm{m} M \mathrm{Na}_{2} \mathrm{HPO}_{4}$ and $2.7 \mathrm{~m} M \mathrm{NaH}_{2} \mathrm{PO}_{4}$; $\mathrm{pH} 7.2$ ) for $1 \mathrm{~min}$, followed by $0.75 \mathrm{~mL}$ of restore solution (10.6 $\mathrm{m} M \mathrm{Na}_{2} \mathrm{HPO}_{4}, 2.7 \mathrm{~m} M \mathrm{NaH}_{2} \mathrm{PO}_{4}$, and $462 \mathrm{mM} \mathrm{NaCl}$; $\mathrm{pH} 7.2$ ), centrifuged at $650 \times \mathrm{g}$ for $10 \mathrm{~min}$ at $4^{\circ} \mathrm{C}$, and repeated until erythrocytes were removed. Once erythrocytes were removed, PBL were resuspended in 1 $\mathrm{mL}$ of PBS. Next, $500 \mu \mathrm{L}$ of the PBL suspension were pelleted and stored at $-80^{\circ} \mathrm{C}$ until further analysis. The remaining cells, $500 \mu \mathrm{L}$ of the PBL suspension, were 
analyzed immediately for expression of cluster of differentiation (CD) 14, CD80, and CD86 by flow cytometry (see "Flow Cytometry" section).

After $24 \mathrm{~h}$ of incubation, cell suspensions were centrifuged for $15 \mathrm{~min}$ at $1,200 \times g$ (Allegra X-15R centrifuge, Beckman Coulter Inc.). Supernatant was removed and stored at $-80^{\circ} \mathrm{C}$ until analysis for $\mathrm{TNF} \alpha$, using a commercially available ELISA kit (Vet Sets ELISA Development Kit; Kingfisher Biotech Inc., St. Paul, MN). A 7-step serially diluted recombinant bovine $\mathrm{TNF} \alpha$ standard curve was used. Samples were run in duplicate. The inter- and intra-assay CV for $\mathrm{TNF} \alpha$ were 16.4 and $2.2 \%$, respectively.

Flow Cytometry. A fraction $(500 \mu \mathrm{L})$ of the PBL suspension from the ex vivo LPS stimulation was diluted with $3 \mathrm{~mL}$ of PBS, vortexed, and centrifuged at $450 \times g$ for $5 \mathrm{~min}$ at $4^{\circ} \mathrm{C}$. Supernatant was discarded, and cells were resuspended. To reduce nonspecific binding, $10 \mu \mathrm{L}$ of recombinant $\mathrm{IgG}(10 \mathrm{mg} / \mathrm{mL})$ was added. Following vortexing, samples were incubated for $10 \mathrm{~min}$ at $4^{\circ} \mathrm{C}$. Next, $20.5 \mu \mathrm{L}$ of the antibody cocktail [ $50 \mu \mathrm{L}$ of CD14 (Invitrogen) plus 1,000 $\mu \mathrm{L}$ of CD80 (Invitrogen) and CD86 (AbD Serotec, Hercules, CA)] were added, vortexed, and incubated for $30 \mathrm{~min}$ at $4^{\circ} \mathrm{C}$. Three milliliters of PBS was added, vortexed, and centrifuged at $450 \times g$ for $5 \mathrm{~min}$ at $4^{\circ} \mathrm{C}$. Supernatant was discarded, cells were resuspended, and $400 \mu \mathrm{L}$ of fluorescenceactivated cell-sorting buffer and $10 \mu \mathrm{L}$ of propidium iodide $(20 \mu \mathrm{g} / \mathrm{mL})$ were added to distinguish dead cells. Samples were read on an Accuri C6 flow cytometer. Data were analyzed using FlowJo software (Treestar, Palo Alto, CA). The percentage of viable cells after $6 \mathrm{~h}$ of incubation with LPS was $68 \pm 9.4 \%$ (SD). The percentage of viable cells after $6 \mathrm{~h}$ of incubation without LPS was $69 \pm 10.6 \%$.

Gene Expression. Relative abundance of select mRNA transcripts of PBL were measured using quantitative PCR analysis. Total RNA was extracted from cell samples dissolved in Trizol reagent, using the standard Trizol method, and eluted with $25 \mu \mathrm{L}$ of RNase-free water. The RNA was quantified using a NanoDrop ND-2000 spectrophotometer (Thermo Fisher Scientific). The average 260/280 ratio was $1.6 \pm$ 0.3 (SD). Complementary DNA was transcribed from RNA using a High-Capacity cDNA Reverse Transcription Kit (Applied Biosystems, Thermo Fisher Scientific) in $20-\mu \mathrm{L}$ reactions that contained $10 \mu \mathrm{L}$ of each RNA sample and $10 \mu \mathrm{L}$ of RNase inhibitor. Samples were incubated at $25^{\circ} \mathrm{C}$ for $10 \mathrm{~min}$, at $37^{\circ} \mathrm{C}$ for 120 min, and at $85^{\circ} \mathrm{C}$ for $5 \mathrm{~min}$. After a 1:10 dilution with DNase-free water, cDNA was stored at $-30^{\circ} \mathrm{C}$. Quantitative PCR was performed using the 7300 Real-Time PCR System (Applied Biosystems, Carlsbad, CA) and the CFX96 Real-Time System (Bio-Rad Laboratories
Inc., Richmond, CA) with gene-specific primers listed in Table 1. Each primer set was tested for specificity and efficiency as previously described (Nelson et al., 2010). Each set was found to result in a single PCR product that corresponded to the correct product size. Primer efficiencies for each gene were $>95 \%$. Amplifications were performed in a $20-\mu \mathrm{L}$ reaction that contained $10 \mu \mathrm{L}$ of SYBR Select Master Mix (Applied Biosystems), $0.5 \mu \mathrm{L}$ each of $10 \mu M$ forward and reverse primers, and $9 \mu \mathrm{L}$ of the 1:10 diluted cDNA sample. Reactions were incubated at $95^{\circ} \mathrm{C}$ for $10 \mathrm{~min}$, followed by 40 cycles at $95^{\circ} \mathrm{C}$ for $15 \mathrm{~s}$ and at $60^{\circ} \mathrm{C}$ for 1 min. Relative qPCR data were analyzed using the delta cycle threshold (CT) values for each target gene obtained after normalization of the $\mathrm{CT}$ value of the gene with the geometric mean of $\mathrm{CT}$ values from the 3 reference genes [ribosomal protein S9 (RPS9), glyceraldehyde-3-phosphate dehydrogenase (GAPDH), and $\beta$-actin $(A C T B)]$ using the formula $[\triangle \mathrm{CT}=\mathrm{CT}$ (gene of interest) - CT (geometric mean)]. The CT values of each reference gene and the geometric mean of the 3 genes were not affected by dietary treatment or LPS stimulation. Statistical analysis was performed using the $\Delta \mathrm{CT}$ values. For interpretation purposes, the $\Delta \mathrm{CT}$ values were transformed by the formula $2^{-\Delta \mathrm{CT}} \times$ 1000 , which results in a transcript abundance value, which is relative to the abundance of transcripts for the reference genes.

Hen Egg Lysozyme Challenge. Effects of experimental treatments on the cow's ability to generate humoral immune responses were assessed by s.c. injection of $7 \mathrm{mg}$ of hen egg lysozyme (HEL; Cat No. L6876, Sigma-Aldrich) at $-28,-14$, and $0 \mathrm{~d}$ relative to parturition. To prepare the HEL injections, HEL was diluted in vehicle [PBS containing $50 \%(\mathrm{~m} / \mathrm{v})$ Quil A adjuvant (Cat No. APO4991; Accurate Chemical, Westbury, NY)] under sterile conditions. Blood was collected with clot activator at $-28,-14,0,7,14,21$, 28,35 , and $49 \mathrm{~d}$ relative to parturition. Serum was separated (60 min at room temperature), centrifuged at $1,125 \times g$ for $20 \mathrm{~min}$, and frozen at $-30^{\circ} \mathrm{C}$. Responses of HEL-specific IgG were measured in serum by ELISA. Briefly, wells of ELISA plates were coated with $100 \mu \mathrm{L}$ of $10 \mu \mathrm{g} / \mathrm{mL}$ of HEL and incubated overnight at $4^{\circ} \mathrm{C}$. Wells were washed 3 times with $300 \mu \mathrm{L}$ of washing buffer [PBS containing $0.05 \%$ ( $\mathrm{vol} / \mathrm{vol}$ ) of Tween 20] and incubated with $100 \mu \mathrm{L}$ of blocking buffer [PBS containing $5 \%$ (wt/vol) of skim milk] for $1 \mathrm{~h}$ at $37^{\circ} \mathrm{C}$. After 3 washings, wells were incubated with $100 \mu \mathrm{L}$ of plasma diluted $1 / 10$ in blocking buffer for $1 \mathrm{~h}$ at $37^{\circ} \mathrm{C}$. Incubation with $100 \mu \mathrm{L}$ of blocking buffer containing a 1:1,000 dilution of alkaline phosphatase-linked secondary antibody specific for goat anti-bovine $\operatorname{IgG}\left(\mathrm{H}^{+} \mathrm{L}\right.$; Cat No. 6030-04; Southern Biotech, Birmingham, AL) 
was allowed for $1 \mathrm{~h}$ at $37^{\circ} \mathrm{C}$ after 3 washings. Wells were then washed and incubated with $100 \mu \mathrm{L}$ of $1 \mathrm{mg} / \mathrm{mL}$ of p-nitrophenyl phosphate in p-nitrophenyl phosphate disodium hexahydrate buffer solution for $1 \mathrm{~h}$ at room temperature and read at $405 \mathrm{~nm}$ using an ELISA plate reader (SpectraMAX 340PC; Molecular Devices LLC, Sunnyvale, CA). Inter- and intra-assay $\mathrm{CV}$ were 1.5 and $0.9 \%$, respectively.

Hematology Analysis. For assessment of hematological characteristics of the systemic blood, whole blood was collected via venipuncture of coccygeal vessels from cows into evacuated tubes (Vacutainer, Becton Dickinson) containing $\mathrm{K}_{2}$ EDTA at 6 and 17 DIM. Samples were gently and frequently inverted, placed on ice, and transported to the laboratory within $3 \mathrm{~h}$ of collection, to be analyzed using the IDEXX ProCyte Dx Hematology Analyzer (IDEXX Laboratories, Inc., Westbrook, ME).

Neutrophil Function. At 6 and 17 DIM, assessment of the percentage of neutrophils undergoing phagocytosis and oxidative burst activity was performed as described previously by Martinez et al. (2012). Blood samples $(\sim 10 \mathrm{~mL})$ were collected by puncture of coccygeal vessels into evacuated tubes containing lithium heparin (Vacutainer, Becton Dickinson). Samples were maintained at room temperature, protected from light, inverted often and gently, and transported to the laboratory for analysis within $3 \mathrm{~h}$ of collection. Upon arrival, samples were kept in a rotation station, to avoid clotting, and protected from light. Preparation of reactions was performed in a laminar airflow hood, following sterile procedures. Briefly, $100 \mu \mathrm{L}$ of whole blood were incubated with $10 \mu \mathrm{L}$ of a $50 \mu M$ dihydrorhodamine 123 solution (Sigma-Aldrich) for 10 min at $37^{\circ} \mathrm{C}$ in a rocker. The positive control consisted of $100 \mu \mathrm{L}$ of sample incubated with $10 \mu \mathrm{L}$ of $20 \mu \mathrm{g} /$ $\mathrm{mL}$ phorbol 12-myristate 13-acetate to induce oxidative burst activity in neutrophils. The negative control consisted of $100 \mu \mathrm{L}$ of sample and $50 \mu \mathrm{M}$ dihydrorhodamine 123. Propidium iodide-labeled Escherichia coli 08:H19 strain KCJ852 isolated from a cow with metritis was added to $100 \mu \mathrm{L}$ of sample (in duplicates) to achieve a bacterium-to-neutrophil ratio of 40 to 1 . The $E$. coli were prepared fresh weekly. Cells were placed on ice to stop neutrophil phagocytosis and oxidative burst activities. An automated lysing system (Q-Prep Epics Immunology Workstation; Coulter Corp., FL) was used to add reagents. Hemolysis was achieved by addition of $500 \mu \mathrm{L}$ of sterile water to each tube, and extracellular fluorescence was suppressed with the addition of $10 \mu \mathrm{L}$ of $0.4 \%$ Trypan Blue Solution (Thermo Fisher Scientific). Samples were analyzed using an Accuri C6 digital analyzer flow cytometer (Becton Dickinson). Neutrophils were gated on the basis of their size and granularity in the density cytogram. Data acquisitions from at least 10,000 cells per sample were analyzed using Flowjo software v. 10.1 (FlowJo LLC, Ashland, OR). Data analyzed were percentage of neutrophils that phagocytized bacteria and the percentage of neutrophils with phagocytosis-induced oxidative burst on the basis of propidium iodide and rhodamine fluoresence. Likewise, histogram analysis for mean fluorescence intensity (MFI) of rhodamine and propidium iodide-labeled bacteria were used as a relative measure of neu-

Table 1. Gene names and primer sequences for real-time quantitative PCR analysis

\begin{tabular}{|c|c|c|c|}
\hline Gene $^{1}$ & Accession no. ${ }^{2}$ & Strand & Sequence \\
\hline \multirow[t]{2}{*}{$G A P D H$} & NM_001034034.2 & Forward & GGCATCCTGACCCTCAAGTA \\
\hline & & Reverse & CACACGGAGCTCGTTGTAGA \\
\hline \multirow[t]{2}{*}{$R P S 9$} & NM_001101152.2 & Forward & GTGAGGTCTGGAGGGTCAAA \\
\hline & & Reverse & GGGCATTACCTTCGAACAGA \\
\hline \multirow[t]{2}{*}{$A C T B$} & NM_173979.3 & Forward & GGCATCCTGACCCTCAAGTA \\
\hline & & Reverse & CACACGGAGCTCGTTGTAGA \\
\hline \multirow[t]{2}{*}{ IL 6} & NM_173923.2 & Forward & TCGCCTGATTGAACCCAGAT \\
\hline & & Reverse & AGGAACGACGAAAGTGTGAGT \\
\hline \multirow[t]{2}{*}{$C X C L 8$} & NM_173925 & Forward & TGCTCTCTGCAGCTCTGTGT \\
\hline & & Reverse & GGTGGAAAGGTGTGGAATGT \\
\hline \multirow[t]{2}{*}{ IL10 } & NM_174088 & Forward & GAGAGTCTTCAGTGAGCTCCAAGAG \\
\hline & & Reverse & TTTGGATGTACTGTTGCTTCTACG \\
\hline \multirow[t]{2}{*}{$I L 1 B$} & NM_174093 & Forward & GCCTTGGGTATCAAGGACAA \\
\hline & & Reverse & TTTGGGGTCTACTTCCTCCA \\
\hline \multirow[t]{2}{*}{ NOS2 } & NM_001076799.1 & Forward & GATCCAGTGGTCGAACCTGC \\
\hline & & Reverse & CAGTGATGGCCGACCTGATG \\
\hline \multirow[t]{2}{*}{ TNFA } & NM_173966 & Forward & GCCCTCTGGTTCAAACACTC \\
\hline & & Reverse & GGGCTACCGGCTTGTTACTT \\
\hline
\end{tabular}

${ }^{1} G A P D H=$ glyceraldehyde 3 -phosphate dehydrogenase, $R P S 9=$ ribosomal protein S9, IL6 = interleukin 6 , $C X C L 8=$ interleukin $8, I L 10=$ interleukin $10, I L 1 B=$ interleukin $1 \beta, N O S 2=$ inducible nitric oxide synthase, $T N F A=$ tumor necrosis factor $\alpha$.

${ }^{2}$ Accession numbers from NCBI database: http://www.ncbi.nlm.nih.gov. 
trophil mean oxidative burst intensity as an indication of the intensity of reactive oxygen species produced per neutrophil and neutrophil mean phagocytic activity as an indication of the concentration of bacteria phagocytized per neutrophil, respectively. Samples were run in duplicate with an intra-assay $\mathrm{CV}$ of $7 \%$.

\section{Statistical Analyses}

Experiment was a randomized complete block design with a $2 \times 2$ factorial arrangement of treatments. Cow was the experimental unit and considered random, along with block. At the time of treatment assignment, prepartum cows from a weekly cohort were blocked by BCS $(3.55 \pm 0.07)$ and mature equivalent 305-d milk yield $[12,115 \pm 315 \mathrm{~kg}(\mathrm{SD})]$ and, within each block, assigned randomly to 1 of the 4 treatments. Descriptive statistics of treatment groups were previously reported (Zenobi et al. 2018a). Pre- and postpartum data were analyzed separately, using the MIXED procedure of SAS version 9.4 (SAS/STAT, SAS Institute Inc., Cary, NC). Because health status can affect most of the parameters that were of interest in this experiment, separate analyses were also performed for data from cows without disease within the first 21 DIM. The REPEATED statement of SAS was used for dependent variables measured over time. Model included the fixed effects of energy intake prepartum (EXE vs. MNE), RPC intake ( $-\mathrm{RPC}$ vs. +RPC), interaction between energy intake prepartum and RPC intake, time of measurement, and all 2- and 3-way interactions. Cow was nested within treatment and was the error term for testing the effects of treatment. Parity was included as a fixed effect and removed if $P>0.10$. The covariance structure with the lowest Akaike's information criterion was selected for each variable, and most analyses used the first-order autoregressive structure for equally spaced measurements or spatial power for unequally spaced measurements. When a significant interaction of treatment with time was detected, treatment means at time points of measure were partitioned using the SLICE command of SAS. The Kenward-Roger method was used to calculate the approximate denominator degrees of freedom for the $F$ tests in the statistical models. Continuous data were tested for the distribution of the residuals after fitting the statistical models using Shapiro-Wilk and homogeneity of variance by plotting residuals against predicted values. Non-normally distributed data were subjected to Box-Cox transformation using the TRANSREG procedure of SAS to achieve normality before analyses. The LSM were back-transformed and SEM calculated as outlined by Jørgensen and Pedersen (1998). Binary responses were analyzed by logistic regression using the GLIMMIX procedure of SAS. The model included the fixed effects of energy intake prepartum (EXE vs. MNE), RPC intake (with vs. without), and the interaction between energy intake prepartum and RPC intake. Statistical significance was declared at $P \leq 0.05$, and tendency was declared at $0.05<P \leq 0.10$.

\section{RESULTS}

\section{Rectal Temperature}

Feeding prepartum diets of different caloric density did not affect mean or pattern of postpartum rectal temperature (Table 2; Figure 1A). Feeding RPC tended $(P=0.07)$ to reduce mean rectal temperature postpartum, mainly due to a decreased $(P<0.05)$ temperature at $12 \mathrm{~d}$ postpartum $(\mathrm{RPC} \times$ day interaction; $P=0.02$; Figure 1B). When cows with no incidence of any clinical disease (retained fetal membranes, mastitis, metritis, respiratory problems, or fever) were analyzed for rectal temperature, the same decreased rectal temperature at 12 d postpartum was observed $(\mathrm{RPC} \times$ day interaction; $P=0.01$; Figure 1D). Treatment did not affect the incidence of cows diagnosed with fever.

\section{Humoral and Cellular Indicators of Immune Status}

Prepartum concentrations of plasma haptoglobin decreased as parturition approached but then rose dramatically, peaking at wk 1 postpartum before decreasing to prepartum concentrations by wk 5 postpartum (effect of week, $P<0.01$; Figures $2 \mathrm{~A}$ and $2 \mathrm{~B}$ ). Feeding EXE prepartum increased $(P=0.02)$ mean haptoglobin concentration prepartum; however, only treatment means at wk -1 differed $(P<0.05$; energy $\times$ wk interaction, $P=0.10$; Figure $2 \mathrm{~A})$. Prepartum dietary energy content did not affect concentrations of haptoglobin postpartum (Table 2). Cows supplemented with +RPC, independent of prepartum diet, had a smaller concentration of haptoglobin in plasma at 2 wk prepartum $(P<0.05)$ compared with $-\mathrm{RPC}$ cows $(\mathrm{RPC} \times$ wk interaction, $P=0.07$; Figure $2 \mathrm{~B})$. Treatment with RPC did not affect plasma concentrations of haptoglobin postpartum (Table 2).

Plasma concentrations of fibrinogen increased 3 - to 4-fold from 2 wk prepartum to 5 wk postpartum (effect of time, $P<0.01$; Table 2 and Figures $3 \mathrm{~A}$ and 3B). Prepartum dietary energy content had no effect on plasma concentrations of fibrinogen during the entire sampling period (Figure 3A). Plasma concentration of fibrinogen at 1 wk postpartum was lower $(P<0.05)$ in cows fed $\mathrm{RPC}$ compared with cows not fed RPC $(\mathrm{RPC} \times$ time interaction, $P=0.05$; Table 2; Figure $3 \mathrm{~B}$ ). A subset of 84 randomly selected cows from the total 93 enrolled had plasma analyzed for concentrations of TNFo. 


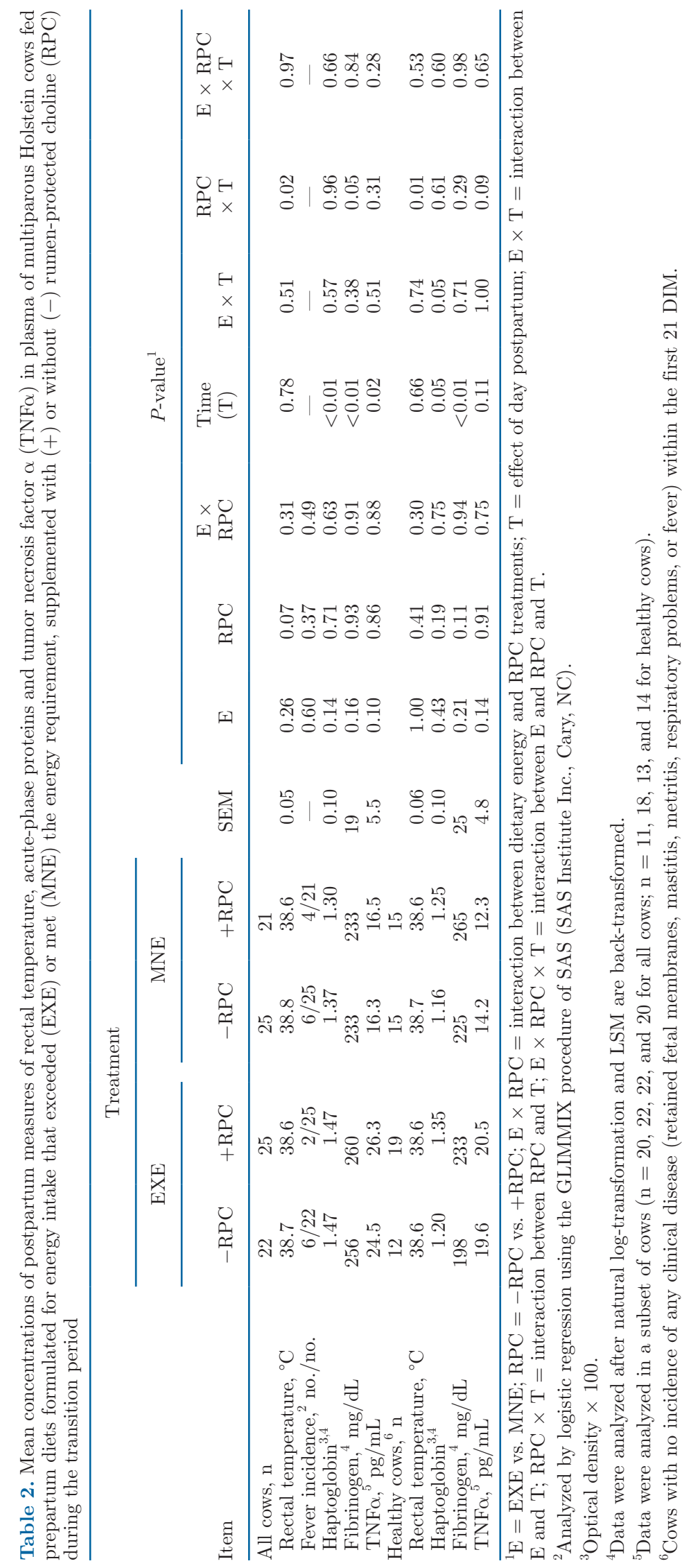


Cows fed EXE tended $(P=0.10)$ to have greater mean plasma concentrations of TNF $\alpha$ postpartum compared with cows fed MNE (Table 2). Because cytokines can be influenced by inflammatory diseases, data for haptoglobin, fibrinogen, and TNF $\alpha$ of cows without disease within the first 21 DIM were also analyzed separately. In healthy cows, concentrations of haptoglobin in cows fed EXE increased to a maximum at 3 wk postpartum, whereas haptoglobin concentrations of cows fed MNE gradually decreased after parturition (energy $\times$ time interaction, $P=0.05$; Table 2; Figure $2 \mathrm{C}$ ). A tendency $(P=0.09)$ for interaction between supplementing RPC and day also was observed for concentrations of TNF . No differences were detected for fibrinogen in heathy cows (Table 2; Figure 3A and B).

Feeding prepartum EXE increased $(P \leq 0.01)$ hematocrit and concentrations of hemoglobin and erythrocytes compared with MNE (Table 3). Prepartum dietary energy content did not affect the concentration of total or particular leukocytes in blood of cows postpartum, with the exception of eosinophils plus basophils, which tended $(P=0.09)$ to comprise a greater percentage of leukocytes in cows fed EXE compared with MNE (Table 3). This increase tended to be most evident at 17 DIM (2.9 vs. $1.7 \%$ ) compared with values at 6 DIM (2.8 vs. $2.5 \%$; energy $\times$ time interaction, $P$ $=0.09$, Table 3 ).

Blood concentrations of lymphocytes tended to increase from 6 to 17 DIM in -RPC cows (11.5 to 12.7 $\left.\times 10^{3} / \mu \mathrm{L}\right)$, but lymphocyte concentrations remained unchanged in $+\mathrm{RPC}$ cows in the same period postpartum $(9.1$ vs. $9.2 \times 1,000 / \mu \mathrm{L} ; \mathrm{RPC} \times$ time interaction, $P=0.10)$. Supplementing RPC tended to decrease the proportion of blood lymphocytes when cows were fed MNE diets prepartum, but the proportion of lymphocytes was unchanged by RPC supplementation when cows were fed the EXE diets prepartum (energy $\times$ RPC interaction, $P=0.08$, Table 3). Treatments did not affect the concentration of neutrophils in blood or the proportion of total leukocytes as neutrophils (Table $3)$. The $+\mathrm{RPC}$ treatment tended $(P=0.06)$ to increase eosinophils plus basophils as a percentage of leukocytes in blood compared with cows not fed RPC (Table 3). The effect of RPC on concentration of eosinophils plus basophils in blood tended to be influenced by the prepartum dietary energy content and day of sampling (Table 3; energy $\times \mathrm{RPC} \times$ time interaction, $P=0.08$ ). Concentration of eosinophils plus basophils in blood was
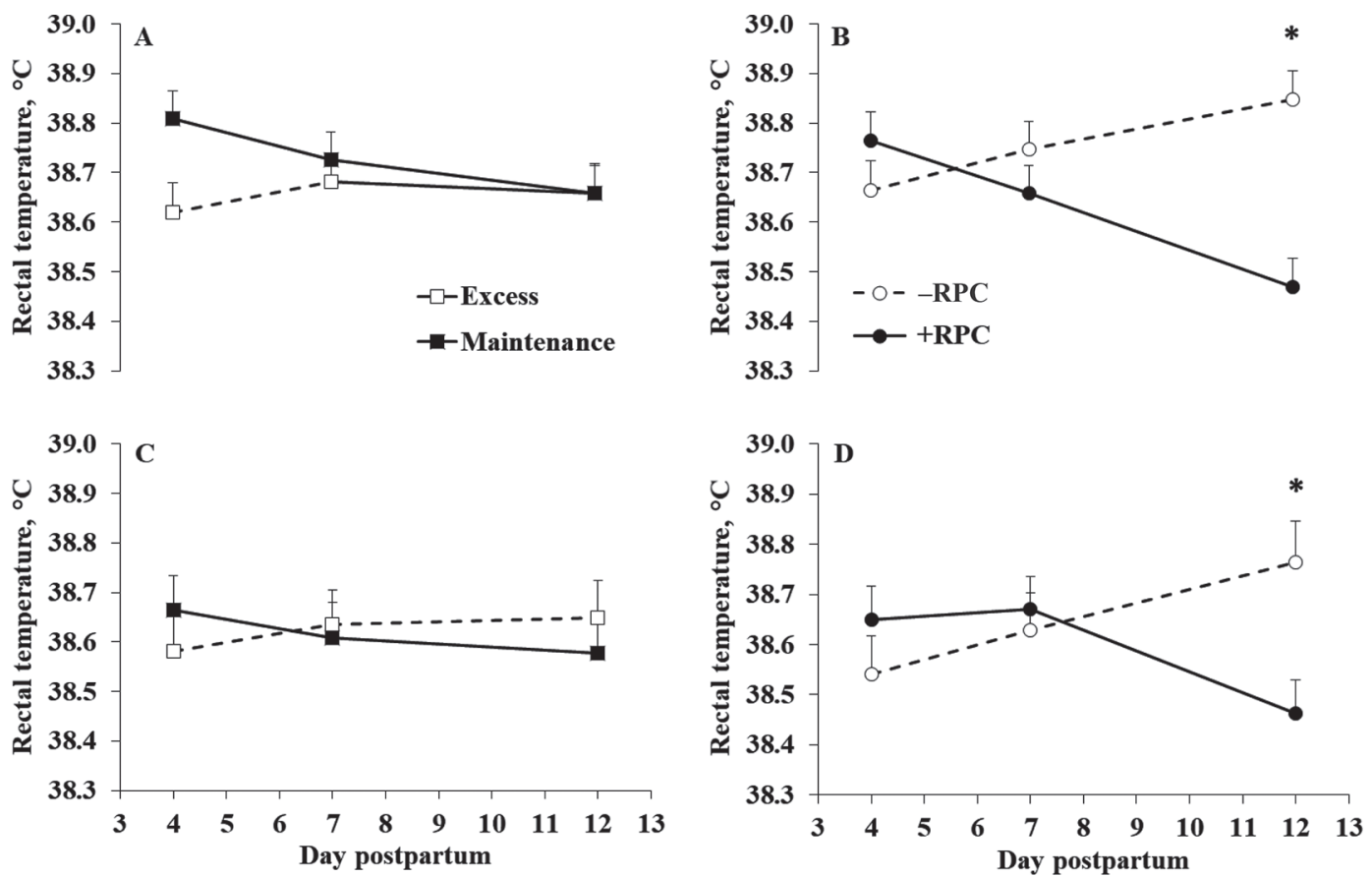

Figure 1. Rectal temperatures of all cows (A and B) and cows without disease within first 21 DIM (C and D). Dairy cows were fed prepartum diets at maintenance or excess energy content (1.40 or $1.63 \mathrm{Mcal}$ of $\mathrm{NE}_{\mathrm{L}} / \mathrm{kg}$ of DM; $\mathrm{A}$ and $\left.\mathrm{C}\right)$ and supplemented without $(-\mathrm{RPC})$ or with $(+\mathrm{RPC})$ rumen-protected choline $(\mathrm{B}$ and $\mathrm{D})$. Panel A: effects of dietary energy $(P=0.26)$ and dietary energy $\times$ day interaction $(P=0.51)$. Panel B: effects of RPC $(P=0.07)$ and RPC $\times$ day interaction $(P=0.02)$. Panel C: effects of dietary energy $(P=0.94)$ and dietary energy $\times$ day interaction $(P=0.73)$. Panel $\mathrm{D}$ : effects of RPC $(P=0.41)$ and $\mathrm{RPC} \times$ day interaction $(P=0.01)$. Within a day, $*$ denotes a difference $(P$ $\leq 0.05)$ between treatments. Error bars denote SEM. 

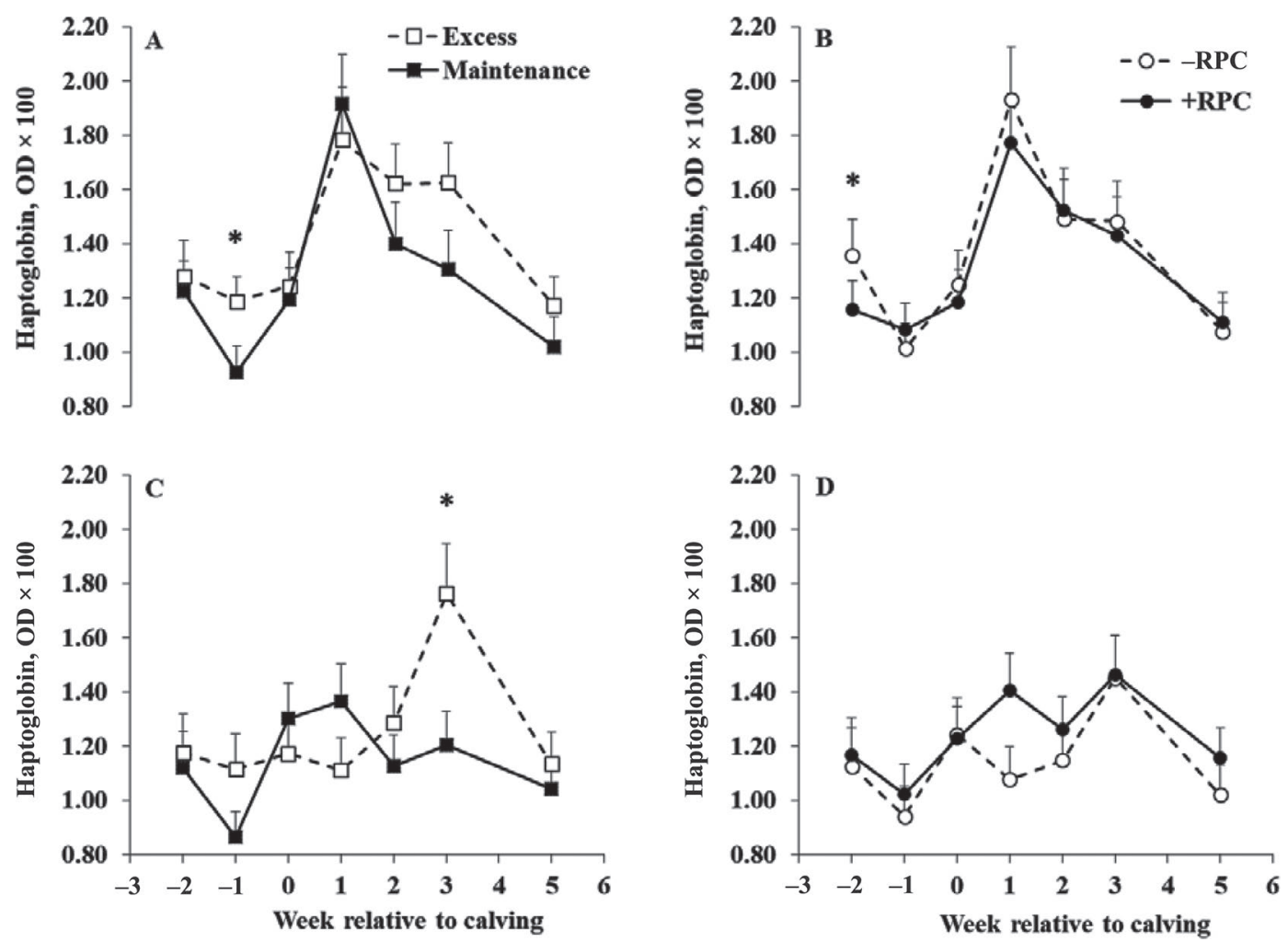

Figure 2. Plasma concentrations of haptoglobin of all cows $(\mathrm{A}$ and $\mathrm{B})$ and cows without disease within first $21 \mathrm{DIM}(\mathrm{C}$ and $\mathrm{D})$. OD $=$ optical density. Dairy cows were fed prepartum diets at maintenance or excess energy content (1.40 or $1.63 \mathrm{Mcal}$ of $\mathrm{NE} / \mathrm{kg}$ of $\mathrm{DM}$; A and $\mathrm{C})$ and supplemented without $(-\mathrm{RPC})$ or with $(+\mathrm{RPC})$ rumen-protected choline $(\mathrm{B}$ and $\mathrm{D})$. Panel A, prepartum: effects of dietary energy $(P=$ $0.02)$ and dietary energy $\times$ week interaction $(P=0.10)$. Panel A, postpartum: effects of dietary energy $(P=0.14)$ and dietary energy $\times$ week interaction $(P=0.57)$. Panel B, prepartum: effects of RPC $(P=0.43)$ and RPC $\times$ week interaction $(P=0.07)$. Panel B, postpartum: effects of $\mathrm{RPC}(P=0.71)$ and RPC $\times$ week interaction $(P=0.96)$. Panel C, prepartum: effects of dietary energy $(P=0.13)$ and dietary energy $\times$ week interaction $(P=0.23)$. Panel $\mathrm{C}$, postpartum: effects of dietary energy $(P=0.43)$ and dietary energy $\times$ week interaction $(P=0.05)$. Panel $\mathrm{D}$, prepartum: effects of RPC $(P=0.54)$ and $\mathrm{RPC} \times$ week interaction $(P=0.79)$. Panel $\mathrm{C}$, postpartum: effects of $\mathrm{RPC}(P=0.19)$ and $\mathrm{RPC} \times$ week interaction $(P=0.61)$. Within a week, ${ }^{*}$ denotes difference $(P \leq 0.05)$ between treatments. Error bars denote SEM.

reduced at 17 compared with 6 DIM in all treatments, with the exception of cows fed EXE diets without RPC, which experienced a rise in concentration over time.

Relative HEL-specific IgG concentrations were measured, to assess how dietary treatments affected the ability of cows to generate humoral immune responses. Concentration of serum IgG against HEL rose approximately 4 -fold in the first $7 \mathrm{~d}$ postpartum, but treatments did not affect HEL-specific IgG concentrations postpartum (Supplemental Figure S1; https://doi.org/ 10.3168/jds.2019-17378). Similar results were observed in analysis of data from cows with no disease (data not shown).

\section{Ex Vivo Indicators of Immune Status}

Supplementation of RPC increased $(P \leq 0.05)$ phagocytosis and oxidative burst and tended $(P=0.09)$ to increase MFI of oxidative burst at 17 DIM compared with 6 DIM $(\mathrm{RPC} \times$ time interaction, Table 4 and
Figures 4A, B, and D). Prepartum dietary energy content did not influence ex vivo function of postpartum neutrophils in blood.

The abundance of NOS2 and all cytokine transcripts were greater $(P<0.05)$ when PBL were stimulated with LPS compared with unstimulated cells, with the increase being most dramatic for $C X C L 8$ and $I L 1 B$ (Supplemental Figure S2; https://doi.org/10.3168/jds .2019-17378). Because incidence of disease may affect leukocyte responses to LPS, we analyzed data for all cows $(\mathrm{n}=93)$ and healthy cows as healthy cows ( $\mathrm{n}$ $=61$; cows without disease in the first 21 DIM). In the analysis of data from all cows, the abundance of transcripts for $T N F$ was greater $(P=0.02)$ for cows fed EXE compared with MNE (Table 5). Feeding RPC, however, attenuated the rise in TNF abundance from $3 \mathrm{~d}$ to $14 \mathrm{~d}$ in cows fed EXE, whereas feeding RPC did not appear to affect TNF over time in cows fed MNE (effect of energy $\times \mathrm{RPC} \times$ time, $P=0.09$; Table 5 ). Likewise, feeding RPC decreased $I L 1 B$ at $14 \mathrm{~d}$, com- 

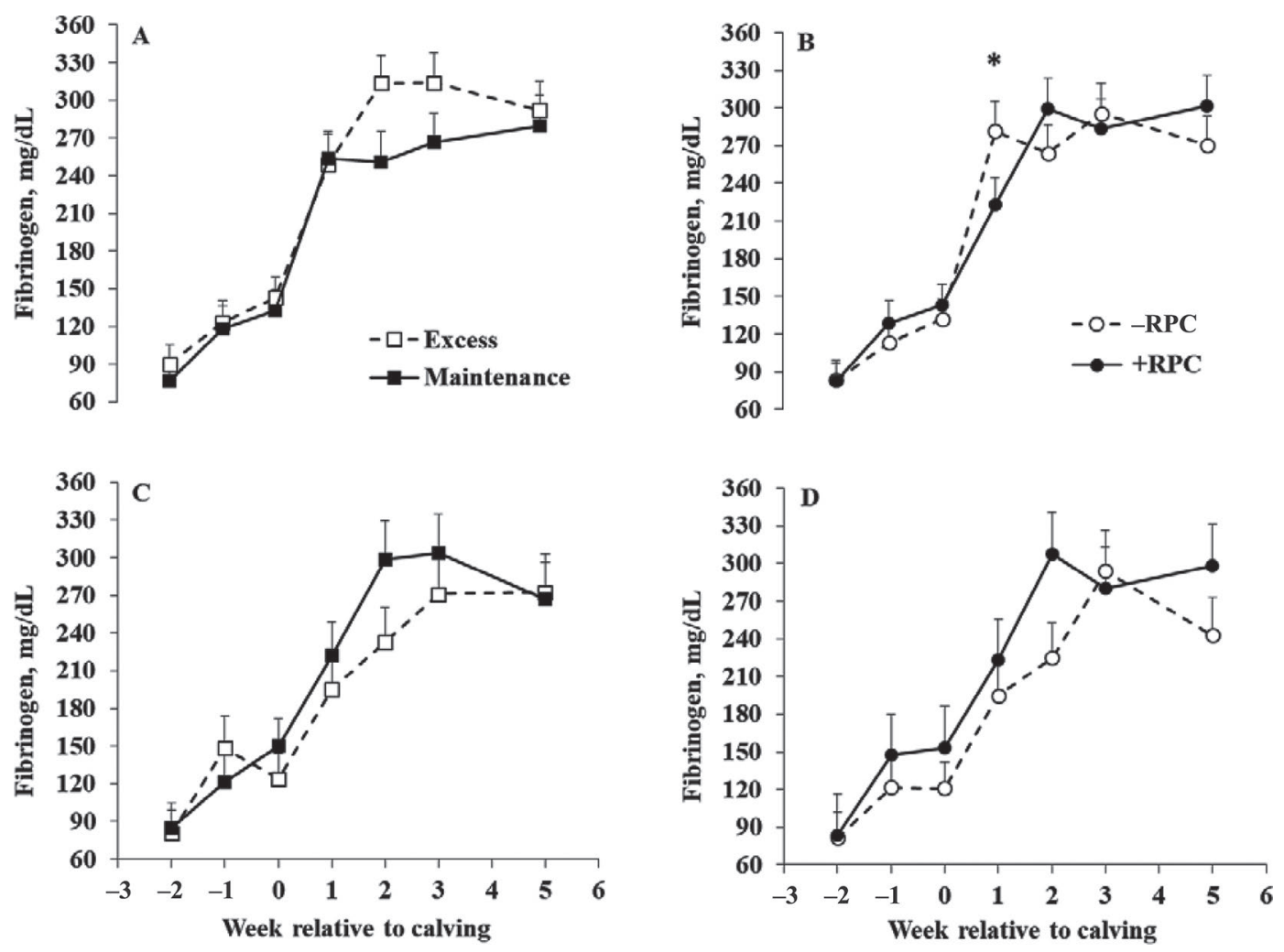

Figure 3. Plasma concentrations of fibrinogen of all cows (A and B) and cows without disease within first 21 DIM (C and D). Dairy cows were fed prepartum diets at maintenance or excess energy content (1.40 or $1.63 \mathrm{Mcal}$ of $\mathrm{NE}_{\mathrm{L}} / \mathrm{kg}$ of DM; A and C) and supplemented without $(-\mathrm{RPC})$ or with $(+\mathrm{RPC})$ rumen-protected choline $(\mathrm{B}$ and $\mathrm{D})$. Panel A, prepartum: effects of dietary energy $(P=0.54)$ and dietary energy $\times$ day interaction $(P=0.46)$. Panel A, postpartum: effects of dietary energy $(P=0.16)$ and dietary energy $\times$ time interaction $(P=0.38)$. Panel $\mathrm{B}$, prepartum: effects of $\mathrm{RPC}(P=0.69)$ and $\mathrm{RPC} \times$ day interaction $(P=0.46)$. Panel $\mathrm{B}$, postpartum: effects of $\mathrm{RPC}(P=0.93)$ and $\mathrm{RPC} \times$ day interaction $(P=0.05)$. Panel $\mathrm{C}$, prepartum: effects of dietary energy $(P=0.70)$ and dietary energy $\times$ day interaction $(P=0.22)$. Panel $\mathrm{C}$, postpartum: effects of dietary energy $(P=0.21)$ and dietary energy $\times$ time interaction $(P=0.71)$. Panel $\mathrm{D}$, prepartum: effects of RPC $(P=$ $0.62)$ and $\mathrm{RPC} \times$ day interaction $(P=0.40)$. Panel $\mathrm{D}$, postpartum: effects of $\mathrm{RPC}(P=0.11)$ and $\mathrm{RPC} \times$ day interaction $(P=0.29)$. Within a day, $*$ denotes difference $(P \leq 0.05)$ between treatments. Error bars denote SEM.

pared with $3 \mathrm{~d}$ for cows fed EXE, but did not appear to affect $I L 1 B$ for cows fed MNE (effect of energy $\times$ RPC $\times$ time, $P=0.04$; Table 5).

In the analyses of data from only healthy cows, LPS-stimulated PBL of healthy cows fed the EXE diet prepartum had more $(P \leq 0.04)$ transcripts for $I L 1 B$, $C X C L 8$, and TNF compared with those of healthy cows fed MNE diets prepartum (Table 5). In contrast, LPSstimulated PBL of cows fed RPC had fewer $(P=0.01)$ transcripts for $I L 1 B$ and $C X C L 8$ than cows not fed RPC (Table 5). Interactions between RPC and day ( $P$ $\leq 0.03$ ) were also detected for $I L 10$ and $T N F$, in that transcripts for IL10 and TNF were both less at 14 DIM in cows fed RPC compared with cows not fed RPC (Table 5; Supplemental Figure S2, https://doi.org/10 $.3168 /$ jds.2019-17378). Supplementation of RPC to healthy cows fed the EXE diet tended to decrease transcripts for IL6, but IL6 was not affected when RPC was supplemented to healthy cows fed the MNE diet (energy $\times \mathrm{RPC}$ interaction, $P=0.07$; Table 5 ).
Dietary treatments affected expression of CD14 and CD80, but not CD86, on LPS-stimulated PBL. At 3 DIM, CD14 expression, as indicated by MFI for the anti-CD14 antibody, tended to be greater for LPS-stimulated PBL from cows fed EXE compared with those fed MNE, whereas CD14 expression at 14 DIM was not affected by prepartum diet (energy $\times$ day interaction, $P=0.06$, Table 6). Feeding RPC to cows fed EXE decreased CD14, but feeding RPC to cows fed MNE increased CD14 (energy $\times$ RPC interaction, $P=0.02$, Table 6). Expression of CD80 on LPS-stimulated PBL decreased in $+\mathrm{RPC}$ compared with $-\mathrm{RPC}(P=0.01$; Table 6).

Peripheral blood leukocyte culture produced more TNFo at 3 than at 14 DIM (effect of day, $P<0.01$, Table 6). As expected, PBL stimulated with LPS produced more TNF $\alpha$ than did nonstimulated PBL across treatments (Table 6). Prepartum dietary energy content did not affect the net increase in concentration of $\mathrm{TNF} \alpha$. The net differences in concentration of $\mathrm{TNF} \alpha$ 
Zenobi et al.: PREPARTUM ENERGY INTAKE AND CHOLINE AFFECT IMMUNITY

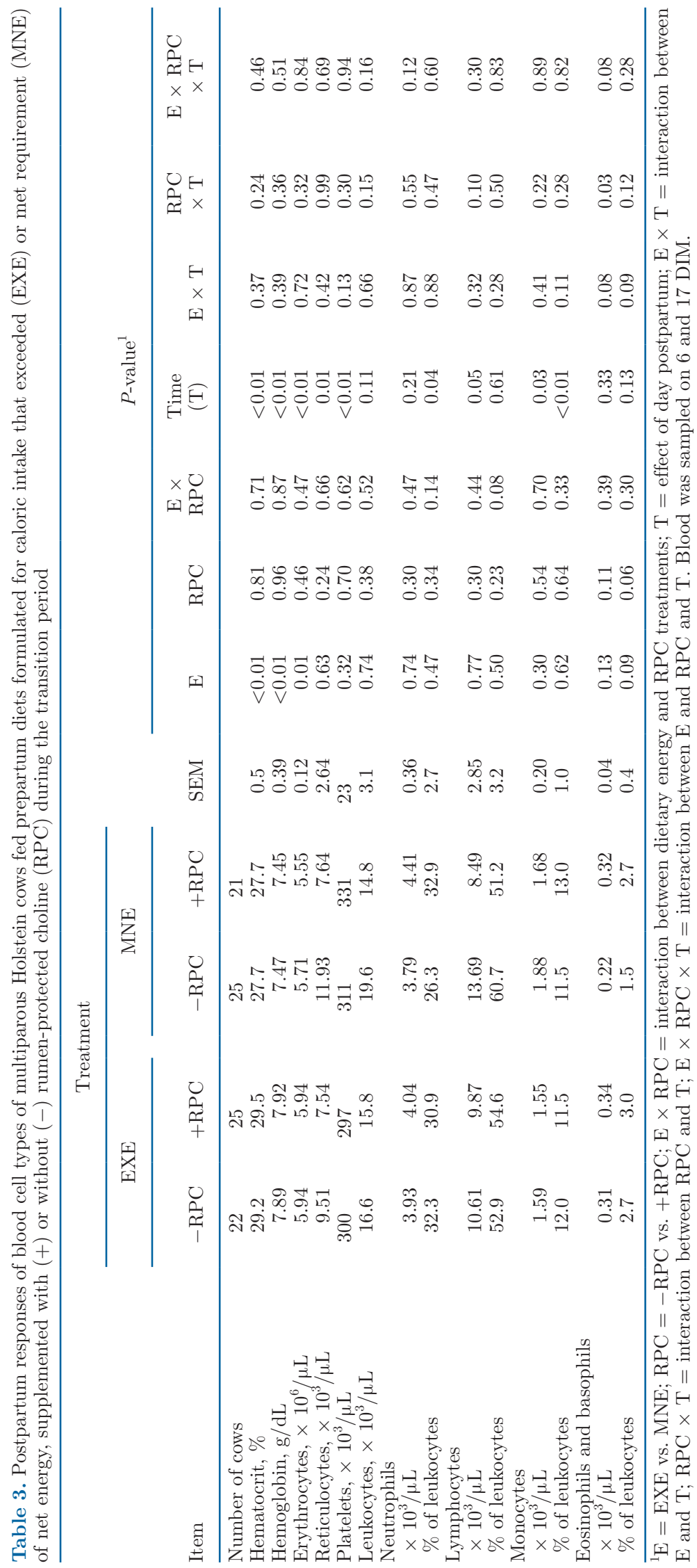




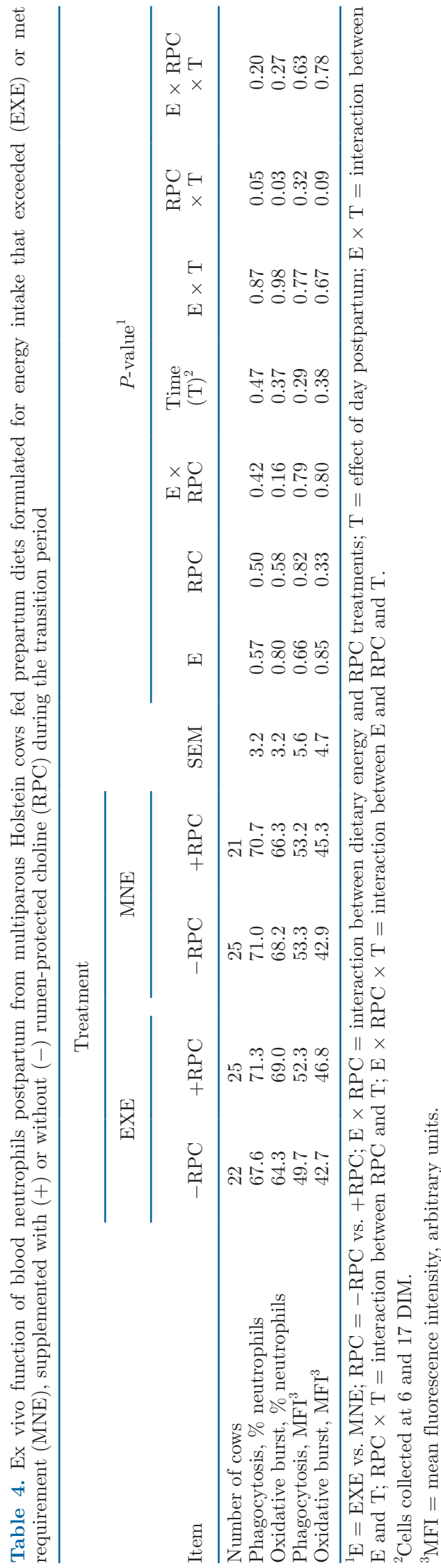

tended to be greater at $3(-\mathrm{RPC}=2.89$ vs. $+\mathrm{RPC}=$ $2.26 \mathrm{ng} / \mathrm{mL})$ compared with $14 \mathrm{DIM}(-\mathrm{RPC}=1.60 \mathrm{vs}$. $+\mathrm{RPC}=1.80 \mathrm{ng} / \mathrm{mL} ; \mathrm{RPC} \times$ time interaction, $P=$ 0.10 ; Table 6).

\section{DISCUSSION}

Feeding RPC to transition dairy cows has documented benefits on subsequent lactation performance (Shahsavari et al., 2016). Here, we observed that feeding RPC to cows overfed energy prepartum modulated their inflammatory state during the postpartum period compared with cows not fed RPC. We also observed that, regardless of prepartum energy intake, cows fed RPC exhibited less inflammation, as evidenced by decreased rectal temperature and decreased plasma concentrations of haptoglobin and fibrinogen. Collectively, these data indicate that transition cows supplemented with RPC experienced less inflammation.

Prepartum diets with moderate to high energy content have been shown to be detrimental for immune function and activity. Wathes et al. (2009) reported that pro-inflammatory immune genes (e.g., CXCL8) were upregulated in the uterine endothelium of dairy cows in severe negative energy balance. In addition, expression of the pro-inflammatory nuclear factor kappa B subunit 1 (NFKB1) gene was greater in blood neutrophils isolated $12 \mathrm{~h}$ after an intramammary challenge with LPS at $7 \mathrm{~d}$ postpartum in cows fed a diet with high compared with maintenance energy content prepartum (Moyes et al., 2014). Graugnard et al. (2013) reported that excess energy intake prepartum resulted in greater concentrations of circulating acute-phase proteins after an LPS challenge postpartum compared with cows fed to maintenance prepartum, even though an LPS challenge had no effect on hepatic expression of TNF. Several parameters measured in this experiment indicate that dairy cows fed diets with excess energy content during the dry period also were more predisposed to inflammation compared with cows fed a prepartum diet at maintenance energy content. Specifically, increased concentrations of haptoglobin and TNFa in plasma and increased transcripts of TNF, IL1B, and CXCL8 after ex vivo stimulation of PBL with LPS were detected in cows fed the EXE compared with the MNE diet. Evidences of greater inflammation in the current experiment were accompanied by a more negative energy state postpartum, greater circulating concentrations of fatty acids and BHB, and greater concentration of triacylglycerol in the liver, as reported by Zenobi et al. (2018a). Overall, results support the idea that overconsumption of calories during the entire dry period may create a more pro-inflammatory state postpartum. 
Supplementing RPC appeared to attenuate the inflammatory state that is often increased in postpartum cows. For example, the rectal temperatures of cows fed RPC decreased with increasing DIM, whereas that of cows not fed RPC increased during the first 12 DIM. Furthermore, LPS-stimulated PBL from cows fed RPC had decreased TNF expression at 14 DIM, and the increase in TNFo concentrations in response to LPS at 3 DIM tended to be less pronounced in PBL of cows fed RPC. Supplementing RPC to EXE cows also reduced abundance of IL6 transcripts in PBL of cows fed EXE diets but not on PBL of cows fed MNE diets. These findings are in agreement with Sun et al. (2016), who reported that RPC supplementation during the transition period decreased the circulating concentration of IL-6 and TNFo, with a concomitant increased yield of FCM. Likewise, injecting LPS into the blood of rats fed a choline-deficient diet elevated serum concentrations of TNF $\alpha$ to a much greater extent compared with rats given LPS and fed a choline-adequate diet (Eastin et al., 1997). Collectively, on the basis of our findings and previous reports, it is reasonable to propose that RPC supplementation may decrease inflammation associated with the metabolic transition that dairy cows experience at the onset of lactation.

The effect of feeding RPC on inflammatory status, particularly rectal temperature, may contribute to the benefits of RPC on lactation performance. Regardless of the cause, an elevated inflammatory state requires energy and nutrients that would otherwise be available to support lactation. Thus, the decreased rectal temperatures of cows fed RPC potentially indicate that they had a smaller demand for energy to support inflammatory processes, resulting in greater availability of energy for lactation. The oxidative environment associated with chronic inflammation also may dampen the functional capacity of immune cells. Although we did not observe an effect of feeding RPC on development of an antibody response to HEL immunization in the present experiment, we found that neutrophil function, as indicated by phagocytosis and oxidative burst, was improved at 17 DIM in cows supplemented with RPC. In agreement, RPC supplementation tended to increase oxidative burst of neutrophils in lactating
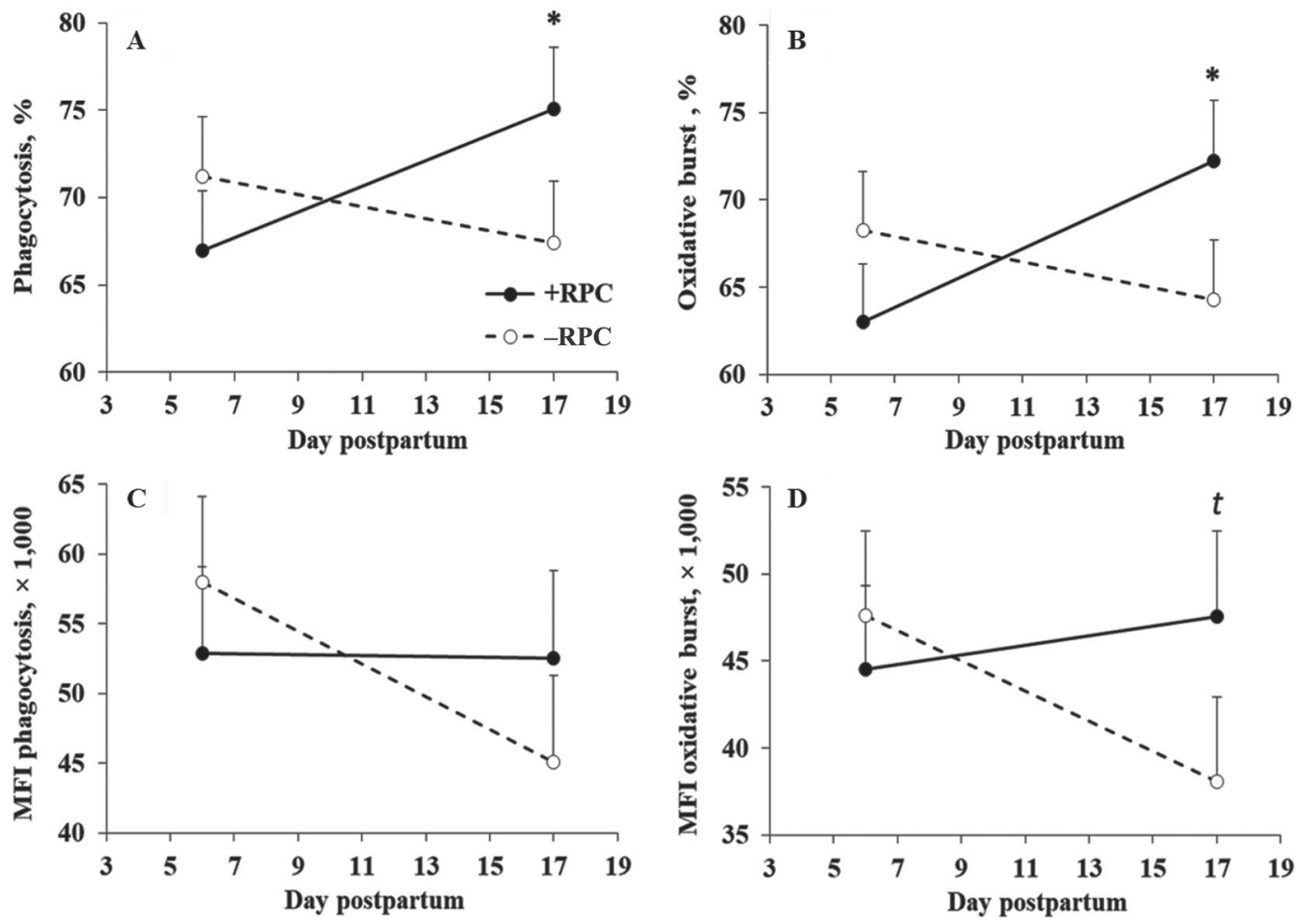

Figure 4. Proportions of neutrophils exhibiting phagocytosis (A) and oxidative burst (B), and mean fluorescence intensity (MFI) of phagocytosis $(\mathrm{C})$ and oxidative burst (D) by neutrophils from dairy cows fed diets differing in energy content and supplemented without ( $-\mathrm{RPC})$ or with $(+\mathrm{RPC})$ rumen-protected choline. Panel A: effects of RPC $(P=0.50)$, day $(P=0.47)$, and interaction between $\mathrm{RPC}$ and day $(P=0.05)$. Panel B: effects of RPC $(P=0.58)$, day $(P=0.37)$, and interaction between RPC and day $(P=0.03)$. Panel C: effects of RPC $(P=0.82)$, day $(P=0.29)$, and interaction between RPC and day $(P=0.32)$. Panel D: effects of RPC $(P=0.33)$, day $(P=0.38)$, and interaction between $\mathrm{RPC}$ and day $(P=0.09)$. Within a day, ${ }^{*}$ denotes difference $(P \leq 0.05)$, and $t$ denotes tendency $(0.05<P \leq 0.10)$ between treatments. Error bars denote SEM. 


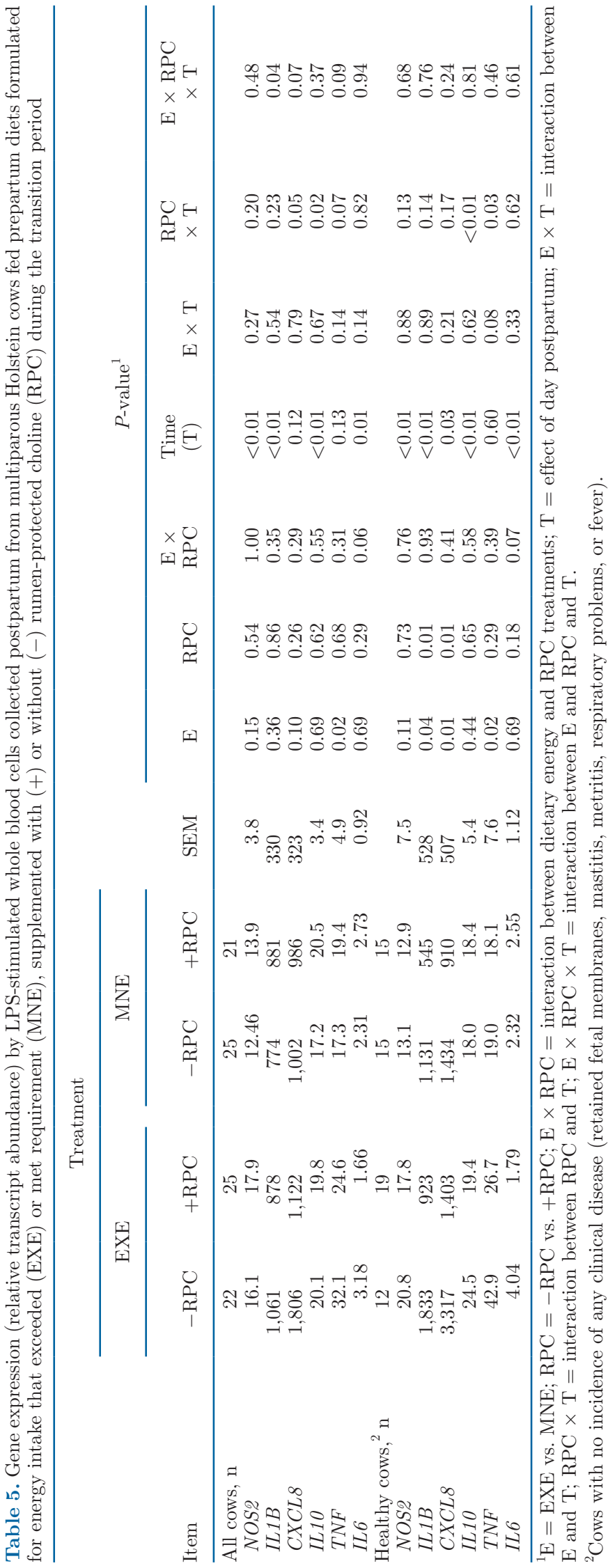

dairy cows (Vailati-Riboni et al., 2017). The improved neutrophil function from feeding RPC may contribute to reduction in postpartum metritis and mastitis, as reported by Lima et al. (2012). Altogether, feeding RPC potentially has beneficial influences on lactation and functional capacities of neutrophils, in part by decreasing inflammation.

Elucidating the mechanisms through which feeding RPC may dampen indicators of inflammation is complex and will require further experimentation. Plausible explanations for the effects of feeding RPC on the differences we observed here include increased supply of choline derivatives that directly affect cell signaling or indirectly affect inflammatory mediators, as a result of changes in lipid metabolism. One possible explanation for the observed ex vivo responses to LPS is that choline supplementation increased the ratio of phosphatidylcholine to phosphatidylinositol in the cell membrane and altered downstream signaling of leukocytes to LPS stimulation (Grove et al., 1990). Expression of several surface molecules, including CD14 and CD80/86 [glycosyl phosphatidylinositol anchored protein that is intercalated in the outer lipid layer of the plasma membrane in humans (Wright et al., 1990; Brunschwig et al., 1999)], is crucial to trigger an immune response during LPS exposure. When LPS binds to CD14, the MyD88-dependent signaling pathway is triggered (Ingalls et al., 1999; da Silva Correia et al., 2001), which induces production of pro-inflammatory cytokines. The costimulatory molecules CD80 and CD86 provide secondary activation signals for the induction of $\mathrm{T}$ cell responses. In the current experiment, expression of CD14 was decreased in LPS-stimulated PBL from cows fed EXE diets and supplemented with RPC. Inhibition of LPS sensitivity by inactivation of toll-like receptor 4 in rats also decreased serum concentrations of IL- 6 and low-grade inflammation (Bomfim et al., 2012). Thus, one possibility is that RPC supplementation increases the ratio of phosphatidylcholine to phosphatidylinositol in the plasma membrane of macrophages, causing a reduction in CD14-TLR4 activation, thereby reducing inflammation (Rivera at al., 1998). Hence, we propose that supplementing RPC in the diet of periparturient cows may modulate intracellular signaling in leukocytes by enhancing phosphatidylcholine concentrations of cell membranes. Unfortunately, we do not have a measure of phosphatidylcholine concentrations in leukocytes to provide support of this hypothesis.

\section{CONCLUSIONS}

Feeding a prepartum diet with excess energy content during the entire dry period resulted in increased indicators of inflammation compared with cows fed to 
Zenobi et al.: PREPARTUM ENERGY INTAKE AND CHOLINE AFFECT IMMUNITY

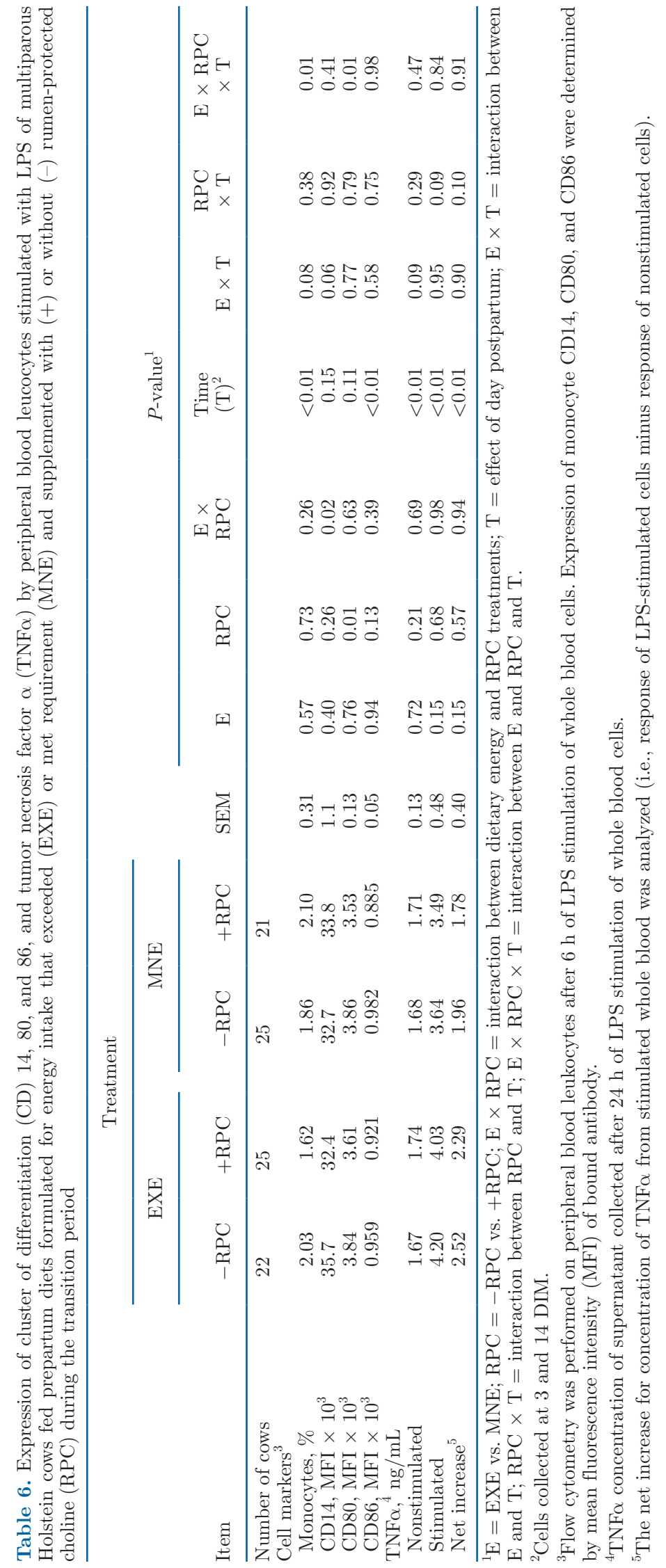


maintenance, as evidenced by increased expression of CXCL8 and TNF in PBL of EXE cows compared with MNE cows. However, feeding RPC to cows seemingly limited inflammation that occurred with parturition, particularly in cows fed EXE, as indicated by decreased expression of IL 6 transcripts and expression of CD14 on leukocytes of EXE - RPC cows during the postpartum period, compared with EXE +RPC cows. In addition, regardless of prepartum dietary energy content, the immune systems of cows fed RPC during the transition period showed decreased indicators of inflammation, as evidenced by reduced rectal temperature in the first 12 DIM, decreased plasma concentrations of haptoglobin prepartum and fibrinogen postpartum, and decreased production of TNFo and abundance of $I L 1 B$ and $C X C L 8$ transcripts in LPS-stimulated PBL. Lastly, supplementing RPC increased the proportion of blood neutrophils undergoing phagocytosis and oxidative burst at 17 DIM, providing evidence for improved innate cellular immune function. Overall, feeding RPC to prepartum cows modulated several parameters of immune status in the postpartum period. We propose that the effects of RPC on immune status may contribute to increased production of milk that results from feeding RPC to prepartum cows.

\section{ACKNOWLEDGMENTS}

Rodrigo Moreira (Federal University of Paraná, Curitiba, Brazil) and André Dias (University of Alberta, Canada) helped ensure proper daily care of cows and collection of samples. Rodrigo Gardinal was supported by a fellowship (\#2014/13132-5) from the São Paulo Research Foundation (Brazil). Special thanks go to Sergei Sennikov (University of Florida, Gainesville) for help with laboratory assays. We thank Raies A. Mier and Kwan Chen Jeong (University of Florida) for preparing the labeled Escherichia coli for neutrophil assays. We also thank Barry Bradford (Kansas State University, Manhattan) for assistance with the TNFo assays. The experiment was partially supported by a grant from Balchem Animal Nutrition and Health (New Hampton, NY). The authors have not stated any conflicts of interest.

\section{REFERENCES}

Ballou, M. A., D. L. Hanson, C. J. Cobb, B. S. Obeidat, M. D. Sellers, A. R. Pepper-Yowell, J. A. Carroll, T. J. Earleywine, and S. D. Lawhon. 2015. Plane of nutrition influences the performance, innate leukocyte responses, and resistance to an oral Salmonella enterica serotype Typhimurium challenge in Jersey calves. J. Dairy Sci. 98:1972-1982. https://doi.org/10.3168/jds.2014-8783.

Bomfim, G. F., R. A. Dos Santos, M. A. Oliveira, F. R. Giachini, E. H. Akamine, R. C. Tostes, Z. B. Fortes, R. C. Webb, and M. H. C. Carvalho. 2012. Toll-like receptor 4 contributes to blood pressure regulation and vascular contraction in spontaneously hypertensive rats. Clin. Sci. (Lond.) 122:535-543. https://doi.org/10 $.1042 /$ CS20110523.

Bradford, B. J., L. K. Mamedova, J. E. Minton, J. S. Drouillard, and B. J. Johnson. 2009. Daily injection of tumor necrosis factor- $\alpha$ increases hepatic triglycerides and alters transcript abundance of metabolic genes in lactating dairy cattle. J. Nutr. 139:1451-1456. https://doi.org/10.3945/jn.109.108233.

Brunschwig, E. B., J. D. Fayen, M. E. Medof, and M. L. Tykocinski. 1999. Protein transfer of glycosyl-phosphatidylinositol (GPI)modified murine B7-1 and B7-2 costimulators. J. Immunother. 22:390-400. https://doi.org/10.1097/00002371-199909000-00002.

Chandler, T. L., and H. M. White. 2017. Choline and methionine differentially alter methyl carbon metabolism in bovine neonatal hepatocytes. PLoS One 12:e0171080. https://doi.org/10.1371/ journal.pone.0171080.

da Silva Correia, J., K. Soldau, U. Christen, P. S. Tobias, and R. J. Ulevitch. 2001. Lipopolysaccharide is in close proximity to each of the proteins in its membrane receptor complex. Transfer from CD14 to TLR4 and MD-2. J. Biol. Chem. 276:21129-21135. https: //doi.org/10.1074/jbc.M009164200.

Eastin, C. E., C. J. McClain, E. Y. Lee, G. J. Bagby, and R. K. Chawla. 1997. Choline deficiency augments and antibody to tumor necrosis factor attenuates endotoxin-induced hepatic injury. Alcohol. Clin. Exp. Res. 21:1037-1041. https://doi.org/10.1111/j.1530 -0277.1997.tb04250.x.

Elek, P., T. Gaal, and F. Husveth. 2013. Influence of rumen-protected choline on liver composition and blood variables indicating energy balance in periparturient dairy cows. Acta Vet. Hung. 61:59-70. https://doi.org/10.1556/AVet.2012.053.

Farney, J. K., L. K. Mamedova, B. H. Godsey, and B. J. Bradford 2011. Technical note: Validation of an ELISA for measurement of tumor necrosis factor alpha in bovine plasma. J. Dairy Sci. 94:3504-3509. https://doi.org/10.3168/jds.2010-4082.

Graugnard, D. E., K. M. Moyes, E. Trevisi, M. J. Khan, D. Keisler, J. K. Drackley, G. Bertoni, and J. J. Loor. 2013. Liver lipid content and inflammometabolic indices in peripartal dairy cows are altered in response to prepartal energy intake and postpartal intramammary inflammatory challenge. J. Dairy Sci. 96:918-935. https:// doi.org/10.3168/jds.2012-5676.

Grove, R. I., N. J. Allegretto, P. A. Kiener, and G. A. Warr. 1990. Lipopolysaccharide (LPS) alters phosphatidylcholine metabolism in elicited peritoneal macrophages. J. Leukoc. Biol. 48:38-42. https:/ /doi.org/10.1002/jlb.48.1.38.

Grummer, R. R. 1993. Etiology of lipid-related metabolic disorders in periparturient dairy cows. J. Dairy Sci. 76:3882-3896. https://doi .org/10.3168/jds.S0022-0302(93)77729-2.

Harris, H. W., C. Grunfeld, K. R. Feingold, T. E. Read, J. P. Kane, A. L. Jones, E. B. Eichbaum, G. F. Bland, and J. H. Rapp. 1993 Chylomicrons alter the fate of endotoxin, decreasing tumor necrosis factor release and preventing death. J. Clin. Invest. 91:10281034. https://doi.org/10.1172/JCI116259.

Imhasly, S., C. Bieli, H. Naegeli, L. Nyström, M. Ruetten, and C. Gerspach. 2015. Blood plasma lipidome profile of dairy cows during the transition period. BMC Vet. Res. 11:252. https://doi.org/10 $.1186 / \mathrm{s} 12917-015-0565-8$.

Ingalls, R. R., H. Heine, E. Lien, A. Yoshimura, and D. Golenbock. 1999. Lipopolysaccharide recognition, CD14, and lipopolysaccharide receptors. Infect. Dis. Clin. North Am. 13:341-353. https:// doi.org/10.1016/S0891-5520(05)70078-7.

Ingvartsen, K. L., R. J. Dewhurst, and N. C. Friggens. 2003. On the relationship between lactational performance and health: is it yield or metabolic imbalance that cause production diseases in dairy cattle? A position paper. Livest. Prod. Sci. 83:277-308. https:// doi.org/10.1016/S0301-6226(03)00110-6.

Janovick, N. A., and J. K. Drackley. 2010. Prepartum dietary management of energy intake affects postpartum intake and lactation performance by primiparous and multiparous Holstein cows. J. Dairy Sci. 93:3086-3102. https://doi.org/10.3168/jds.2009-2656.

Jørgensen, E., and A. R. Pedersen. 1998. How to obtain those nasty standard errors from transformed data-And why they should not 
be used. Biometry Res. Unit Int. Rep. 7. Danish Inst. Agric. Sci. $1-20$.

Lima, F. S., M. F. Sá Filho, L. F. Greco, and J. E. P. Santos. 2012. Effects of feeding rumen- protected choline on incidence of diseases and reproduction of dairy cows. Vet. J. 193:140-145. https://doi .org/10.1016/j.tvjl.2011.09.019.

Makimura, S., and N. Suzuki. 1982. Quantitative determination of bovine serum haptoglobin and its elevation in some inflammatory diseases. Nihon Juigaku Zasshi (Jpn. J. Vet. Sci). 44:15-21. https: //doi.org/10.1292/jvms1939.44.15.

Martinez, N., C. A. Risco, F. S. Lima, R. S. Bisinotto, L. F. Greco, E. S. Ribeiro, F. Maunsell, K. N. Galvão, and J. E. P. Santos. 2012. Evaluation of peripartal calcium status, energetic profile, and neutrophil function in dairy cows at low or high risk of developing uterine disease. J. Dairy Sci. 95:7158-7172. https://doi.org/ $10.3168 /$ jds.2012-5812.

Merriman, K. E., N. Martinez, R. M. Rodney Harris, E. Block, J. E. P. Santos, and C. D. Nelson. 2019. Neutrophil $\beta$-defensin gene expression of postpartum dairy cows is altered by prepartum dietary cation-anion difference. J. Dairy Sci. 102:11636-11651. https://doi .org/10.3168/jds.2019-17216.

Moyes, K. M., D. E. Graugnard, M. J. Khan, M. Mukesh, and J. J. Loor. 2014. Postpartal immunometabolic gene network expression and function in blood neutrophils are altered in response to prepartal energy intake and postpartal intramammary inflammatory challenge. J. Dairy Sci. 97:2165-2177. https://doi.org/10.3168/jds .2013-7433.

Nelson, C. D., T. A. Reinhardt, T. C. Thacker, D. C. Beitz, and J. D. Lippolis. 2010. Modulation of the bovine innate immune response by production of 1alpha,25-dihydroxyvitamin $\mathrm{D}(3)$ in bovine monocytes. J. Dairy Sci. 93:1041-1049. https://doi.org/10 $.3168 /$ jds.2009-2663.

Pinotti, L. 2012. Vitamin-like supplementation in dairy ruminants: The case of choline. In Milk Production: An Up-to-Date Overview of Animal Nutrition, Management and Health. Narongsak Chaiyabutr, ed. InTech, Rijeka, Croatia. https://doi.org/10.5772/ 50770 .

Read, T. E., C. Grunfeld, Z. Kumwenda, M. C. Calhoun, J. P. Kane, K. R. Feingold, and J. H. Rapp. 1995. Triglyceride-rich lipoproteins improve survival when given after endotoxin in rats. Surgery 117:62-67. https://doi.org/10.1016/S0039-6060(05)80231-4.

Rivera, C. A., M. D. Wheeler, N. Enomoto, and R. G. Thurman. 1998. A choline-rich diet improves survival in a rat model of endotoxin shock. Am. J. Physiol. 275:G862-G867. https://doi.org/10.1152/ ajpgi.1998.275.4.G862

Shahsavari, A., M. J. D'Occhio, and R. Al Jassim. 2016. The role of rumen-protected choline in hepatic function and performance of transition dairy cows. Br. J. Nutr. 116:35-44. https://doi.org/10 $.1017 / \mathrm{S} 0007114516001641$.

Sun, F., Y. Cao, C. Cai, S. Li, C. Yu, and J. Yao. 2016. Regulation of nutritional metabolism in transition dairy cows: Energy homeostasis and health in response to post-ruminal choline and methionine. PLoS One 11:e0160659. https://doi.org/10.1371/journal.pone .0160659 .

Vailati-Riboni, M., Z. Zhou, C. B. Jacometo, A. Minuti, E. Trevisi, D. N. Luchini, and J. J. Loor. 2017. Supplementation with rumenprotected methionine or choline during the transition period influences whole-blood immune response in periparturient dairy cows. J. Dairy Sci. 100:3958-3968. https://doi.org/10.3168/jds.2016 -11812 .

Waldron, M. R., B. J. Nonnecke, T. Nishida, R. L. Horst, and T. R. Overton. 2003. Effect of lipopolysaccharide infusion on serum macromineral and vitamin $\mathrm{D}$ concentrations in dairy cows. J. Dairy Sci. 86:3440-3446. https://doi.org/10.3168/jds.S0022 -0302(03)73948-4.

Wathes, D. C., Z. Cheng, W. Chowdhury, M. A. Fenwick, R. Fitzpatrick, D. G. Morris, J. Patton, and J. J. Murphy. 2009. Negative energy balance alters global gene expression and immune responses in the uterus of postpartum dairy cows. Physiol. Genomics 39:1-13. https://doi.org/10.1152/physiolgenomics.00064.2009.

Wright, S. D., R. A. Ramos, P. S. Tobias, R. J. Ulevitch, and J. C Mathison. 1990. CD14, a receptor for complexes of lipopolysaccharide (LPS) and LPS binding protein. Science 249:1431-1433. https: //doi.org/10.1126/science.1698311.

Zenobi, M. G., R. Gardinal, J. E. Zuniga, A. L. G. Dias, C. D. Nelson, J. P. Driver, B. A. Barton, J. E. P. Santos, and C. R. Staples. 2018a. Effects of supplementation with ruminally protected choline on performance of multiparous Holstein cows did not depend upon prepartum caloric intake. J. Dairy Sci. 101:1088-1110. https: //doi.org/10.3168/jds.2017-13327.

Zenobi, M. G., T. L. Scheffler, J. E. Zuniga, M. B. Poindexter, S. R. Campagna, H. F. Castro Gonzalez, A. T. Farmer, B. A. Barton, J. E. P. Santos, and C. R. Staples. 2018b. Feeding increasing amounts of ruminally protected choline decreased fatty liver in nonlactating, pregnant Holstein cows in negative energy status. J. Dairy Sci. 101:5902-5923. https://doi.org/10.3168/jds.2017-13973.

Zerbe, H., N. Schneider, W. Leibold, T. Wensing, T. A. M. Kruip, and H. J. Schuberth. 2000. Altered functional and immunophenotypical properties of neutrophilic granulocytes in postpartum cows associated with fatty liver. Theriogenology 54:771-786. https://doi .org/10.1016/S0093-691X(00)00389-7. 